\title{
Cost and Margin Analysis of Processed Agroindustry Product Marketing In Mataram City
}

\author{
Suprianto*, Putu Karismawan, Eka Agustiani \\ Department of Economics Development Studies, Faculty of Economics and Business, University of Mataram, Mataram City, Indonesia
}

Email address:

pithikngguyu@gmail.com (Suprianto),Supriantodrs23@gmail.com (Suprianto)

${ }^{*}$ Corresponding author

To cite this article:

Suprianto, Putu Karismawan, Eka Agustiani. Cost and Margin Analysis of Processed Agroindustry Product Marketing In Mataram City. Humanities and Social Sciences. Vol. 9, No. 5, 2021, pp. 155-164. doi: 10.11648/j.hss.20210905.14

Received: August 6, 2021; Accepted: August 21, 2021; Published: September 26, 2021

\begin{abstract}
This study aims to determine the marketing pattern of processed agro-industry products, examine the margins of each marketing agency, the profit of the institution and marketing channels, and the level of marketing efficiency in each marketing channel of processed agro-industry products in the city of Mataram. The type of research used is descriptive using quantitative and qualitative data. Data was collected through interviews with the help of questionnaires. The data analysis used is qualitative and quantitative analysis by calculating marketing margins, profits and efficiency in each marketing agency and marketing channel. The results obtained are the marketing system of processed agro-industrial products in the city of Mataram consisting of three marketing channels, namely from producers $=>$ collectors $=>$ retailers $=>$ final consumers. In my marketing channel, the leather cracker collectors have a margin of Rp. $15,000 / \mathrm{Kg}$, while in the marketing channel that has the highest margin in this channel is the retailer, which is Rp. $20,000 / \mathrm{Kg}$. Bread processed products with a marketing margin of IDR 250 / pack at retailers, then salted peanut products have a marketing margin of IDR 15,000 / kg in marketing channels I and II, Tofu and tempeh products have a marketing margin of IDR 250 / fruit (retailers) and IDR 750 /pack tempe for collectors and Rp 500/pack for retailers. Salted egg processed products have a marketing margin of Rp. 1000/egg in channel I and Rp. 500/egg in channel II. Marketing efficiency can be seen from the total marketing margin and farmer's share, where in Marketing Channels 1,2 , and 3 , it can be seen that all marketing channels for processed agro-industry products are included in the efficient marketing level. The three marketing channels are efficient based on the acquisition of farmer's share which is above 50 percent. The costs incurred in each marketing channel consist of transportation costs, labor costs, and packaging costs. The cheaper the costs incurred, the more efficient the marketing channel and this is in the second marketing channel (the average marketing efficiency is $2.1 \%$ ).
\end{abstract}

Keywords: Cost Analysis, Marketing Margins, Processed Agroindustry Product

\section{Introduction}

\subsection{Background}

The development of agro-industry is a must in order to achieve an agricultural-based industrial society, both largescale agro-industry and small-scale agro-industry such as home agro-industry. Agribusiness and agro-industry are two business activities in the agricultural sector that are able to increase people's income both in rural and urban areas and can accommodate a large enough non-skilled workforce. According to Kartasasmita, M [7] defines agro-industry in two ways, namely first, agro-industry as an industry with the main raw materials from agricultural products and secondly, agro-industry as a stage of development as a continuation of agricultural development but before the development stage reaches the stages of industrial development.

These agro-industry activities generally involve small and medium-sized enterprises which are small-scale people's economic activities with various shortcomings and obstacles that this small and medium-sized business group has. However, experience shows that small and medium-sized enterprises or industries have resilience to global economic shocks, besides that small and medium-sized industries also have considerable capabilities to provide jobs, open up business opportunities, absorb labor and provide income to 
the community to ensure life more prosperous.

West Nusa Tenggara as one of the national food buffer areas based on the development of the agricultural sector, especially rice, secondary crops, vegetables, tubers and livestock products has considerable potential in the development of agribusiness and agro-industry processing agricultural inputs. Processed products from these agricultural inputs, besides being able to meet the needs of local communities and also to meet demands from other regions, include supporting the activities of the tourism sector in the form of culinary tourism and souvenirs of NTB typical food products. Especially in the city of Mataram as the center of government and trade, there are various small and medium industries engaged in various fields of processing agricultural inputs, one of which is the food processing industry.

Agroindustry starts from two approaches, namely the raw material supply approach is used because there are many available raw materials, but have not been utilized so that their value is low. The processing of these raw materials will increase the added value of these raw materials, while the market demand approach is used because it sees market opportunities for products resulting from the processing of these raw materials [21]. In this case, processing agroindustry products such as tofu, tempeh, cowhide crackers, pindang, jackfruit lunkhead, various chips and so on are products that are consumed daily by people both living in rural areas and urban communities. Recently, this processed product has penetrated the modern market and tourism market as a typical regional souvenir which is often found in modern outlets and even local markets. So the market for processed agro-industry products plays a big enough role in delivering these processed products into the hands of household consumers as well as for traders and hotel consumers as providers of raw materials for processed products, especially in Mataram City which is a trading base city, hotels, restaurants and education centers.

This research was conducted to follow up on the results of previous studies related to the added value of processed agroindustrial products in the city of Mataram, and furthermore the researchers wanted to target those related to the marketing and costs (marketing margins) of processed agro-industrial products in the city of Mataram. The base of this research is in the Seganteng and Abianbadan neighborhoods, Sandubaya sub-districts and Cakranegara sub-districts, Mataram City, which are producing areas of processed agro-industrial products such as tofu, tempeh, skin crackers and so on whose production is large enough to meet market demand. The market is one of the places where agricultural and marine products are marketed or sold to serve the needs of the community both for household needs and for the needs of businesses/food traders, hotels, and restaurants whose growth is increasing in the city of Mataram [1], especially the city of Mataram has been included in the series activities in national culinary tours and can even penetrate the foreign culinary market or the international market. This is a challenge for culinary business people in the city of Mataram to serve a variety of hygienically processed ready-to-eat foods and food products typical of Lombok which are increasingly in demand by the people of Mataram city and outside the region.

\subsection{Problem Formulation}

Referring to the description of the problem in this research, the formulation of the problem can be drawn as follows:

1. How much are the production costs incurred by the entrepreneur in one production process of the processed Agro industry.

2. How are the marketing channels and marketing costs for processed agro-industry products from producers to consumers.

\subsection{Research Purposes}

1. To analyze the elements of production costs and marketing costs of processed agro-industry products in the Seganteng and Abianbadan neighborhoods, Sandubaya District.

2. To analyze the marketing distribution and marketing margins of processed agro-industry products from producers to consumers.

\section{Literature Review}

\subsection{Agricultural Industry Concept}

The concept of small industry according to the Ministry of Industry and Trade together with BPS defines a small industry as an economic activity carried out by individuals or households or an entity that aims to produce goods or services for commercial commerce, which has a net worth of at most IDR 200,000,000 and has the total value is greater than that of large and medium industries [18].

Along with the development and progress of the times as well as the development of science and technology (IPTEK) it will result in a trend of transformation patterns from agriculture to industry, which is known that the industrial sector is one of the contributors to the economy in Indonesia. One of them is the food industry sector, which processes agricultural products, both vegetable and animal, into processed products. In particular, the food industry in Indonesia has considerable business prospects in the future because its existence is always needed to meet people's needs for food goods, because the need for food is a primary need for humans who prioritize food needs over other needs.

Business in agriculture or better known as Agribusiness is an activity related to handling agricultural commodities, in a broad sense which includes one or the whole of the production chain, processing of industrial inputs and outputs (Agro-industry), marketing of agricultural inputs and outputs and supporting institutional activities [6].

Agribusiness activities are inseparable from agro-industry whose business activities use agricultural products as inputs or industrial processing of agricultural products and trade. The development of agro-industry is a must in order to achieve an agricultural-based industrial society. 


\subsection{Definition of Processing Agroindustry}

Agroindustry is an industry that processes primary agricultural commodities into processed products, both intermediate and finished products, including post-harvest handling, food and beverage processing industry, biopharmaceutical industry, bio-energy industry, processing industry. by-products and the agro-tourism industry to support the tourism sector (Directorate General of Agricultural Product Processing and Marketing [2].

Agroindustry can be classified as resource oriented economic activity because raw materials are weight-losing industries and have the following characteristics:

a. The raw material is easily damaged or spoiled so that it requires processing or manufacture as soon as possible.

b. The raw materials experience a reduction in weight after undergoing manufacture and this requires an agroindustrial location (manufacturing factory) that is near the source of raw materials to save costs.

The main priority of agro-industry development is focused on the synergy between the comparative advantage of resources and market orientation, namely [2]:

a. Plantation product processing industries such as palm oil and coconut processing industry, processed chocolate industry, sugar industry, processed cashew seed industry, powder/instant coffee industry and processed tea industry.

b. Food and horticultural product processing industry, such as canned fruit and vegetable industry, fruit juice beverage industry, tapioca flour industry and its derivatives, animal feed industry, and snack food industry.

c. The livestock product processing industry, such as the processed milk industry, the canned meat industry, and the leather tanning industry.

d. Processing industries of by-products/by-products such as agro-composting industry, animal feed industry, coco fiber and coco peat industry, activated carbon industry, cashew fruit beverage industry and nata de-coco industry and others.

Agroindustry consists of 3 factors, namely raw materials, processes and markets. Existing raw materials are processed or converted by applying process technology into products and then the resulting products are sold to consumers.

\subsection{Production Cost Analysis}

Production costs are all economic expenses that must be incurred to produce an item. Production costs are also expenses made by the company to obtain production factors and raw materials that will be used to produce a product.

According to Prasetyo [13], cost is the value of all necessary economic inputs that can be estimated and can be measured to produce a product.

Cost is the amount of money issued by producers to finance production activities. In the production process, the factors of production are combined, processed and then produce a final result which is usually called a product.
Production costs are intended as the amount of compensation received by the owner of the production elements used in the production process concerned.

There are four categories or groupings of costs [18]:

a. Fixed costs are costs that are not used up in one production period.

b. Variable costs or variable costs are costs whose size is very dependent on the cost of production scale.

c. The cash costs of fixed costs can be in the form of water and land taxes, while for variable costs for external labor costs.

d. Non-cash costs (calculated) include fixed costs and family labor costs.

e. The costs used for production can be divided into two kinds, namely:

f. . Explicit costs are costs that are actually paid during the production process by producers for inputs (inputs) originating from outside such as the use of labor and production facilities from outside.

g. The cost (implicit) is the cost of the factors of production themselves that are included in the production process to produce the product (output).

h. Included in these costs are depreciation costs. Rent own land. Wages for family labor and interest on own capital.

To calculate the total cost of production can be calculated using the formula:

$$
\mathrm{TC}=\mathrm{TVC}+\mathrm{TFC}
$$

Information:

$$
\begin{aligned}
& \text { TC }=\text { Total Cost (in Rupiah) } \\
& \text { TVC }=\text { Total Variable Cost (in Rupiah) } \\
& \text { TFC }=\text { Total Fixed costs (in Rupiah) }
\end{aligned}
$$

\subsection{Definition of Marketing}

In general, marketing is a business activity aimed at distributing goods and services from producers to consumers in order to provide satisfaction from the exchange of goods and services, namely between sellers and buyers. According to Sa'id et al [19], marketing is all business activities aimed at providing satisfaction from goods or services exchanged to consumers or users. So marketing is a combination of activities that bring together buyers and sellers in an exchange in a place called the market or other places where producers provide their products and buyers come to buy these products.

Marketing is a managerial and process by which individuals and groups obtain what they need and want by creating, sharing, and exchanging value with others [3].

In marketing, there is a flow of goods from producers to consumers by involving marketing intermediaries. All marketing intermediary institutions play a very important role in determining marketing channels, because if it consists of a long marketing chain, the marketing costs incurred will be greater.

According to Soekartawi [17], marketing costs are costs 
incurred for marketing purposes, including transportation costs, sorting costs, packaging costs, and labor costs used [17]. The more efficient the marketing is done, the smaller the marketing costs incurred. The amount of marketing costs differ from one another due to: (a) the type of commodity, (b) the marketing location, (c) the type of marketing agency and (d) the effectiveness of the marketing carried out.

\subsection{Marketing Channel}

The marketing channel or marketing distribution is a means that bridges the products produced by producers so that these products reach the hands of final consumers. In marketing activities, there are several channels that are passed by producers to deliver their products to the market and this is a link in marketing activities. According to Pranata Gama et al, [14], agricultural marketing distribution channels organize agricultural commodities from producers to consumers, through several marketing channels:

1. Zero Level Channel, where this zero level channel is also known as a direct channel, meaning that producers directly sell their goods to consumers, so in this case producers do not use intermediaries.

The flow: MANUFACTURER $\rightarrow$ CUSTOMER

2. Level one channel (One Level Channel), is called a level one channel because there is only one intermediary institution, where the intermediary agency for consumer goods in general is through retailers.

The flow: MANUFACTURER $\rightarrow$ RETAILER CUSTOMER (CONSUMER)

3. The second level channel (To Level Channel), is called the second level channel because there are two intermediaries and for consumer goods in general the intermediary institutions are wholesalers and retailers.

Flow: MANUFACTURER $\rightarrow$ WHOLESALE RETAILER $\rightarrow$ CUSTOMER

4. Multi-level channels are called multi-level channels because they involve many intermediaries, this is usually in addition to wholesalers and retailers, there are also collectors and each intermediary leads to other intermediaries, and usually this form of channel is more suitable for marketing / distribute consumer goods and non-industrial goods.

The flow:

\section{MANUFACTURERS $\quad \rightarrow \quad$ WHOLESALE}

\section{DISTRIBUTORS $\rightarrow$ CUSTOMERS $\rightarrow$ RETAILERS}

By looking at the marketing chain mentioned above, there are differences in costs and prices received by each marketing agency.

\subsection{Marketing Margin}

In general, the marketing margin is the difference in the price of an item received by producers and the price paid by consumers. To see marketing efficiency through margin analysis, the distribution of profit margin ratios or profit margin ratios (RPM) can be used for each marketing agency involved in the marketing process. The profit margin ratio is the ratio between the level of profit earned and the costs incurred by each relevant marketing agency.

Marketing margin is a term used to express the difference between the price paid to the first seller and the price paid by the final buyer. Marketing costs will be higher if many marketing channels are involved in marketing institutions for a product before the product reaches the final consumer.

All economic activities, including marketing, require efficiency. There are four criteria that can be used as indicators of marketing efficiency, namely (1) marketing margins, (2) prices at the consumer level, (3) the availability of physical and marketing facilities, and (4) the level of market competition. However, marketing margin indicators are used more often because through marketing margin analysis it can be seen the level of operational efficiency (technology) and price efficiency (economics) of a marketing [18].

Mathematically, the calculation of marketing margin is formulated as:

$$
\mathrm{mji}=\text { Psi }- \text { Pbi or } \mathrm{mji}=\text { bti }+\mathrm{i}
$$

mji $=$ Margin at i-level marketing agency

Psi $=$ Selling price at marketing agency level $i$-th $(\mathrm{i}=1,2,3, \ldots \ldots ., \mathrm{n})$

$\mathrm{Pbi}=$ Purchase price at level marketing agency $\mathrm{i}$-th

Bti $=$ Marketing agency level marketing costs $i-$ th

$\mathrm{i}=$ Profit of the i-level marketing agency

Marketing Channel Analysis is a set of organizations that depend on each other, both in providing products or services that are used by consumers. Marketing agencies aim to market products and adjust supply and demand. Efficient marketing channels can reduce gaps or risks that will occur, such as the risk of late delivery or misplaced ownership.

Margin can show added value from farmers to consumers. This margin analysis can be used to analyze the marketing system from a macro perspective (marketing products from farmers to consumers). The formula for marketing margin can be seen as follows:

$$
\mathrm{MT}=\operatorname{Pr}-\mathrm{Pf}
$$

Information:

MT = Total Margin

$\operatorname{Pr}=$ Price at the consumer level $(\mathrm{Rp} / \mathrm{kg})$

$\mathrm{Pf}=$ Price at producer level $(\mathrm{Rp} / \mathrm{kg})$

Farmers share

Farmer share is the percentage of the price received by producers with the price paid by consumers. Several things affect farmer share, including the level of processing, transportation costs, number of products, and product durability. Farmer share is negatively related to marketing margin. The higher the marketing margin, the lower the share received by farmers. Farmer share can be calculated by the formula:

$$
\mathrm{FS}=\mathrm{P} \_\mathrm{f} / \mathrm{P} \_\mathrm{r} \times 100 \text { percent }
$$

Information:

$\mathrm{FS}=$ Percentage received by Farmers (part of price) 


\section{Research Methods}

\subsection{Types of Research}

This study uses a descriptive analysis method, namely to examine the status of a human group, an object, a set of conditions, a system of thought or a class of events in the present [11]. The descriptive method describes events in a systematic, factual and accurate manner regarding the facts, nature and relationships between the phenomena studied. This study aims to make a systematic, factual and accurate picture or painting of the marketing performance of processed agro-industry products in the research area.

\subsection{Place and Time of Research}

This research was conducted in the city of Mataram, namely in the areas of Seganteng and Abianbadan, Sandubaya District, Karang Taliwang, Cakranegara District. The objects in this research are entrepreneurs of tofu and tempeh processing agroindustry, cowhide crackers, bread, salted peanuts and salted egg businesses. The research period required is 6 (six) months, starting from May to November 2020 .

\subsection{Research Sample}

The determination of the sample in this study was carried out by the researcher taking the sample using the "purposive sampling" technique. This refers to the opinion of Sugiyono [16], that purposive sampling is a sampling technique with certain considerations from the researcher. This means that each subject taken from the population is chosen intentionally based on certain objectives and considerations of the researcher. Determination of the size of the sample in this study were as many as 6 business units of respondents from each business unit of beef skin crackers, salted peanuts, tofu, tempeh, and salted duck eggs.

\subsection{Data Type}

This study uses primary data and secondary data to support the analysis, namely:

1. Primary data were obtained directly from processed agro-industry entrepreneurs, namely processed Tofu, processed Tempe and processed beef skin crackers, salted peanuts, shredded and duck eggs by direct observation and interviews with respondents, namely business owners, retailers and collectors by referring to the list. prepared questions.

2. While secondary data is data obtained from related agencies and various literatures related to this research.

\subsection{Data Analysis}

The data that has been collected from the respondents is then processed and analyzed qualitatively and quantitatively in the following order:

\section{Economic analysis}

Analysis of Processed Agro-industry Costs and Revenues

Revenue analysis is used to determine the total gross receipts, total costs, and net revenues, or to see a comparison between total revenues and total expenditures $(\mathrm{R} / \mathrm{C}=\mathrm{TR} / \mathrm{TC})$. Operating income can be formulated as follows: $=\mathrm{TR}-\mathrm{TC}$

\section{Marketing Margin Distribution}

Margin can show added value from producers to consumers. This margin analysis can be used to analyze the marketing system from a macro perspective (product marketing from producers to consumers). The formula for marketing margin can be seen as follows:

$$
\mathrm{MT}=\operatorname{Pr}-\mathrm{Pf}
$$

Information:

MT = Total Margin

$\mathrm{Pr}=$ Price of potatoes at the consumer level $(\mathrm{Rp} / \mathrm{kg})$

$\mathrm{Pf}=$ Price of potatoes at farm level $(\mathrm{Rp} / \mathrm{kg})$

3. Farmer Share

Farmer share is the percentage of the price received by producers with the price paid by consumers. Several things affect farmer share, including the level of processing, transportation costs, number of products, and product durability. Farmer share is negatively related to marketing margin. The higher the marketing margin, the lower the share received by farmers. Farmer share can be calculated by the formula:

$$
\mathrm{FS}=\mathrm{P} \_\mathrm{f} / \mathrm{P} \_\mathrm{r} \times 100 \text { percent }
$$

Information:

FS= Percentage received by Producer

\section{Results and Discussion}

\subsection{Mataram City Area}

The city of Mataram is divided into three regions, namely the City of Cakranegara as a commercial center city, the City of Mataram as the center of education and government and the old city of Ampenan as a supporting city for tourism and demographics of the population in the city of Mataram spread over 6 (six) sub-districts namely; Cakranegara subdistrict, Sandubaya sub-district, Selaparang sub-district, Ampenan sub-district, Mataram sub-district and Sekarbela sub-district with the following population distribution:

Table 1. Mataram City Population in 2018-2020.

\begin{tabular}{lllllll}
\hline \multirow{2}{*}{ District } & Male & & \multicolumn{5}{c}{ Female } \\
\cline { 2 - 7 } & $\mathbf{2 0 1 8}$ & $\mathbf{2 0 1 9}$ & $\mathbf{2 0 2 0}$ & $\mathbf{2 0 1 8}$ & $\mathbf{2 0 1 9}$ \\
\hline Ampenan & $46.662,00$ & $47.890,00$ & $48.275,00$ & $46.052,00$ & $46.874,00$ & $47.666,00$ \\
Mataram & $43.852,00$ & $45.820,00$ & $44.851,00$ & $45.670,00$ & $46.717,00$ \\
Cakranegara & $33.611,00$ & $33.774,00$ & $33.898,00$ & $34.508,00$ & $34.681,00$ & $47.742,00$ \\
\hline
\end{tabular}




\begin{tabular}{lllllll}
\hline \multirow{2}{*}{ District } & Male & & \multicolumn{3}{l}{ Female } \\
\cline { 2 - 6 } & $\mathbf{2 0 1 8}$ & $\mathbf{2 0 1 9}$ & $\mathbf{2 0 2 0}$ & $\mathbf{2 0 1 8}$ & $\mathbf{2 0 1 9}$ \\
\hline Sandubaya & $39.464,00$ & $40.650,00$ & $41.824,00$ & $39.716,00$ & $40.916,00$ \\
Sekarbela & $35.825,00$ & $37.147,00$ & $38.473,00$ & $36.746,00$ & $38.107,00$ & $\mathbf{2 0 2 0}$ \\
Selaparang & $36.812,00$ & $36.878,00$ & $36.900,00$ & $38.558,00$ & $38.631,00$ & $39.481,00$ \\
Kota Mataram & $236.226,00$ & $240.789,00$ & $245.190,00$ & $241.250,00$ & $245.926,00$ \\
\hline
\end{tabular}

Sumber: BPS Kota Mataram.

Furthermore, the population in 2020 is a prediction figure described by the dukcapil office of the city of Mataram where in 2020 the male population is 245,190 people and the female population is 250,491 people or the total population in 2020 is 495,681 people or an increase from the previous year of $1.84 \%$.. The sizeable increase in population must be balanced with various basic needs for food, clothing and housing, which demand quite a lot, especially the demand for processed products, both as raw materials and processed food products.

\subsection{Marketing Channel}

So the marketing channel is an activity carried out by several institutions involved in conveying or selling processed agroindustry products from the hands of producers to final consumers. The distribution of processed agro-industry products involves several intermediary traders whose roles are very important in order to convey or distribute processed products in the city of Mataram in a series of marketing activities. The marketing actors of processed agro-industry products in the city of Mataram include:

The marketing channel in this research is through two marketing channels, namely:

Channel 1: Manufacturers $\rightarrow$ Collectors $\rightarrow$ Retailers

Channel 2: Manufacturers $\rightarrow$ Retailers

\subsubsection{Cost and Revenue Analysis}

This study took several samples of food processing industry business groups in the city of Mataram, namely; processing industry for skin crackers, bread, salted peanuts, tofu, tempeh and salted eggs. Sampling of processed agroindustry respondents was carried out purposively with the consideration that the processed foods mentioned above are foods that become daily consumption for residents of the city of Mataram and for residents outside the city of Mataram. As an illustration of the amount of business and production costs and the average income of the processed industry business in a month can be seen in the following table:

Table 2. Average Production Cost and Income of Processed Agroindustry in Mataram.

\begin{tabular}{lllll}
\hline No & Type of Business & Production Value (IDR) & Production Cost (IDR) & Revenue (IDR) \\
\hline 1 & Cowhide Crackers & 45.000 .000 & 36.250 .000 & 8.750 .000 \\
2 & Bread & 23.500 .000 & 16.639 .825 & 6.360 .175 \\
3 & Salted Peanuts & 21.000 .000 & 16.950 .000 & 5.050 .000 \\
4 & Tofu & 31.000 .000 & 21.297 .000 & 6.702 .490 \\
5 & Tempeh & 23.000 .000 & 17.650 .000 & 5.350 .000 \\
6 & Salted egg & 27.500 .000 & 21.450 .000 & 6.050 .000 \\
\hline
\end{tabular}

Source: Data processed (2020).

The average business income of the cowhide processing industry into leather crackers in Seganteng, Sandubaya District in one month is IDR 45,000,000 with an average monthly production of $458 \mathrm{Kg}$ and the average selling price per kilo gram at the producer level is IDR 130,000, - with income IDR 8,750,000,- Furthermore, the business of processing duck eggs into salted eggs in Taliwang, Cakranegara District with a total monthly production of 11,000 eggs with a selling price at the producer level of IDR $2,500,-$ per egg so that the total production value is IDR $27,500,000$,- with a production cost of IDR $21,450,000$,- and a monthly net income of IDR 6,050,000,- Salted Peanuts business in Mandalika sub-district, Sandubaya sub-district, the average production produced is $467 \mathrm{Kg}$ with a production value of IDR. 21,000,000,- at a price of Rp. at the producer level IDR 60,000, - per kg, production costs IDR 16,950,000, - so that the business income of the salted peanut processed industry is a month. esar IDR 5.050.000,- Furthermore, the soybean processing industry into Tofu and Tempe in Kekalik
Jaya, Sekarbela District.

\subsubsection{Marketing Margin Analysis}

The distribution of processed agro-industry products from producing producers to final consumers involves various product marketing agencies. This will cause a price difference between the purchase of the product and the selling price of the product as well as the marketing costs incurred by each marketing agency. The difference between the selling price and the purchase price of a product at each marketing agency involved in a marketing activity is called the Marketing Margin. The marketing of processed products in the Mataram city area generally uses two marketing channels, namely the first channel involving collectors and the second channel retailers and retailers selling them directly in retail to stalls, kiosks and to final consumers. Furthermore, how much is the purchase price and selling price as well as the marketing margin of each one marketing agency can be seen in the following table: 
Table 3. Purchase Price, Selling Price and Marketing Margin of Processed Products.

\begin{tabular}{llll}
\hline Marketing Agency & Purchase Price (kg/unit) (IDR) & Selling Price (kg/unit) (IDR) & Marketing Margin (IDR) \\
\hline I. Crackers Skin & & & - \\
1. Produser & - & 120.000 & 15.000 \\
2. Collecting Merchant & 120.000 & 135.000 & 20.000 \\
3. Retailer Merchant & 135.000 & 155.000 & - \\
II. Bread & - & & 250 \\
1. Produsen & 1.500 & 1.500 & - \\
2. Retailer Merchant & & 1.750 & 15.000 \\
III Kacang Asin & 60.000 & & 15.000 \\
1. Produser & 75.000 & 60.000 & - \\
2. Collecting Merchant & & 75.000 & 250 \\
3. Retailer Merchant & - & 90.000 & - \\
IV Tahu & 1.000 & & 7.000 \\
1. Produser & & 1.250 & 750 \\
2. Retailer Merchant & - & & 500 \\
V Tempe & 3.000 & - & - \\
1. Produser & 3.500 & 3.500 & 1.000 \\
2. Collecting Merchant & & 4.000 & 500 \\
3. Retailer Merchant & - & 2.500 & \\
VI Telur Asin & 2.500 & 3.500 & \\
1. Produser & 3.500 & 4.000 & \\
2. Gathering Merchant & & & \\
3. Retailer Merchant &
\end{tabular}

Source: Data research processced (2020).

The marketing margin for collectors for cracker skin products is IDR 15,000, while the marketing margin for collectors is IDR 20,000 and the marketing margin for retailers is IDR 15,000 . This difference is due to each institution incurring transportation costs as well as packaging costs. Such as salted peanut products where the collectors pack peanuts with sizes of 1 ounce, $\mathrm{kg}$, $\mathrm{kg}$ and one kilo gram size, so that the marketing margin received by collectors is greater than that of retailers, which is IDR 25,000 ,- per $\mathrm{kg}$, while retailers have a margin of IDR, marketing IDR 10,000,-.

Furthermore, the marketing margin for processed tofu and tempeh products where only two marketing institutions are involved here, namely collectors and retailers, with a marketing margin for tofu products from retailers of IDR. 250,- while collectors and retailers for tempe processed products. IDR 500,- and the price received by consumers for one medium-sized package of tempeh is IDR. 4,000,- while the price of tofu received by consumers is IDR 1,250,- for large and small sizes of IDR. 500. breeders amounting to IDR 2,500,- then by the duck egg collectors, they are processed into salted eggs sold by retailers for IDR 3,500,with a marketing margin of IDR 750 ,- per item while retailers sell for IDR. 4,000,- the difference in price received by traders collectors with a marketing margin of IDR 1,000,This is due to the cost of the manufacturing process salted egg preparation, boiling of raw salted eggs into cooked salted eggs that are ready to be consumed.

\subsection{Analysis of Costs and Benefits of Marketing of Processed Products}

Analysis of the production costs of processed agroindustry from several products can be classified into several parts according to business, namely skin crackers, salted peanuts, bread, tofu, tempeh, and salted eggs, especially those used as samples in this study. The calculation of costs and income incurred by producers or entrepreneurs of processed products in this study is calculated on an average of one month. The analysis of the costs incurred by each processed agro-industry entrepreneur depends on the type of product produced and the amount of costs will affect the level of profit obtained by each producer of processed products. The results obtained from the sum of the different marketing agencies and these differences will result in the following marketing margins:

Table 4. Average Costs and Prices, Margin Distribution, Price Share and Marketing Efficiency of Processed Agroindustry Products in Mataram City in 2020.

\begin{tabular}{llll}
\hline $\begin{array}{l}\text { Marketing Institutions and } \\
\text { Components }\end{array}$ & $\begin{array}{l}\text { Cost and Price Marging } \\
\text { (IDR) }\end{array}$ & $\begin{array}{l}\text { Distribution Margin } \\
\text { Ski -- Sbi (\%) }\end{array}$ & $\begin{array}{l}\text { Price Share (\%) } \\
\text { Ski -- Sbi }\end{array}$ \\
\hline $\begin{array}{l}\text { A. Skin Crackers } \\
\text { 1. Produser }\end{array}$ & & \\
a. Business Costs & 95.000 & 81,25 \\
b. Celling Price & 130.000 & & 0 \\
c. Profit & 35.000 & & 16,67 \\
2. Collecting Trades & & 3,125 & 3,33 \\
a. Labor Cost & 5.000 & 0,625 & 80 \\
b. Transpotation Cost & 1.000 & 15 & 3,75 \\
c. Purchase Price & 135.000 & & \\
\hline
\end{tabular}




\begin{tabular}{|c|c|c|c|c|}
\hline $\begin{array}{l}\text { Marketing Institutions and } \\
\text { Components }\end{array}$ & $\begin{array}{l}\text { Cost and Price Marging } \\
\text { (IDR) }\end{array}$ & $\begin{array}{l}\text { Distribution Margin } \\
\text { Ski --- Sbi (\%) }\end{array}$ & $\begin{array}{l}\text { Price Share (\%) } \\
\text { Ski --- Sbi }\end{array}$ & $\begin{array}{l}\text { Marketing Efficiensy } \\
(\%)\end{array}$ \\
\hline d. Selling Price & 155.000 & 3,750 & 20 & \\
\hline e. Profit & 14.000 & & & \\
\hline \multicolumn{5}{|l|}{ B. Breade } \\
\hline \multicolumn{5}{|l|}{ 1. Manufacturer } \\
\hline a. Cost Business & 900 & 82,5 & & 0 \\
\hline b. Selling Cost & 1.650 & & & \\
\hline c. Profit & 600 & & & \\
\hline \multicolumn{5}{|l|}{ 2. Retailer } \\
\hline a. Marketing Cost & 50 & 2,5 & 16,67 & \\
\hline b. Purchase Price & 1.650 & & & \\
\hline c. Selling Price & 2.000 & 15 & 83,33 & \\
\hline d. Profit & 300 & 2,5 & 16,67 & \\
\hline \multicolumn{5}{|l|}{ C. Salted Peanuts } \\
\hline \multicolumn{5}{|l|}{ 1. Manufacturer } \\
\hline a. Business Costs & 45.000 & 80 & & \\
\hline b. Selling price & 60.000 & & & \\
\hline c. Profit & 15.000 & & & \\
\hline \multicolumn{5}{|l|}{ 2. Collecting Trades } \\
\hline a. Marketing cost & 1.000 & 1,3 & 6,67 & \\
\hline b. Packaging fee & 4.000 & 5,3 & 26,67 & \\
\hline c. Purchase price & 60.000 & 13,33 & 66,66 & \\
\hline d. Selling price & 75.000 & 6,6 & 33,34 & \\
\hline e. Profit & 10.000 & & & \\
\hline \multicolumn{5}{|l|}{ 3. Retailer } \\
\hline a. Marketing costs & 1.000 & 0,17 & 11,12 & \\
\hline b. Purchase price & 75.000 & & & \\
\hline c. Selling price & 85.000 & 10,58 & 88,88 & \\
\hline d. Profit & 9.000 & 0,17 & 11,12 & \\
\hline \multicolumn{5}{|l|}{ D. Tahu } \\
\hline \multicolumn{5}{|l|}{ 1. Manufacturer } \\
\hline a. Business costs & 600 & 80 & & 0 \\
\hline b. Selling price & 1.000 & & & \\
\hline c. Profit & 400 & & & \\
\hline \multicolumn{5}{|l|}{ 2. Retailer } \\
\hline a. Marketing cost & 50 & 4,00 & 25,00 & \\
\hline b. Purchase price & 1.000 & 16,00 & 75 & 4,00 \\
\hline c. Selling price & 1.250 & 4,00 & 25,00 & \\
\hline d. Profit & 200 & & & \\
\hline \multicolumn{5}{|l|}{ E. Tempe } \\
\hline \multicolumn{5}{|l|}{ 1. Manufacturer } \\
\hline a. Business costs & 2.000 & 75 & & 0 \\
\hline b. Selling price & 3.000 & & & \\
\hline c. Profit & 1.000 & & & \\
\hline \multicolumn{5}{|l|}{ 2. Retailer } \\
\hline a. Business costs & 75 & 2,14 & 17,65 & \\
\hline b. Purchase price & 3.000 & 12,14 & 82,35 & 2,14 \\
\hline c. Selling price & 3.500 & 2,14 & 17,65 & \\
\hline d. Profit & 425 & & & \\
\hline \multicolumn{5}{|l|}{ F. Salted egg } \\
\hline 1. Manufacturer & & & & \\
\hline a. Business costs & 1.200 & 71,43 & & 0 \\
\hline b. Selling price & 2.000 & & & \\
\hline c. Keuntungan & 800 & & & \\
\hline 2. Collector & & & & \\
\hline a. Processing costs & 200 & 5,72 & 28,57 & \\
\hline b. Marketing costs & 100 & 2,86 & 14,28 & \\
\hline c. Purchase price & 2.500 & 20,00 & 57,15 & 8,68 \\
\hline d. Selling price & 3.500 & 8,68 & 42,85 & \\
\hline e. Profit & 700 & & & \\
\hline 3. Retailer & & & & \\
\hline a. Marketing costs & 50 & 1,25 & 11,11 & \\
\hline b. Purchase price & 3.500 & 11,25 & 88,89 & 1,25 \\
\hline c. Selling price & 4.000 & 1,25 & 11,11 & \\
\hline d. Profit & 450 & & & \\
\hline
\end{tabular}

Source: Data research (2020). 
Farmer share is the percentage of the price received by producers with the price paid by consumers. Several things affect farmer share, including the level of processing, transportation costs, number of products, and product durability. Farmer share is negatively related to marketing margin. The higher the marketing margin, the lower the share received by farmers. Farmer share can be calculated by the formula:

\section{FS $=\mathrm{Pf} / \operatorname{Pr} \times 100$ percent}

Information:

FS $=$ Percentage received by Producer (price share)

$\mathrm{Pr}=$ Price at the consumer level $(\mathrm{Rp} / \mathrm{kg})$

$\mathrm{Pf}=$ Price at producer level $(\mathrm{Rp} / \mathrm{kg})$

Note: If Fs $>50 \%$, then marketing can be said to be efficient.

After knowing the total marketing margin and farmer's share on the Marketing 1,2, and 3, it can be seen that all marketing channels of processed agroindustry products are included in the efficient marketing level. The three marketing channels are efficient based on the acquisition of each farmer's share which is above 50 percent. In addition, several factors underlie the three channels so that they become efficient marketing channels. These factors are costs, profits, distance, travel time, marketing facilities and infrastructure. In Table 4. it can be seen that the costs incurred in each marketing channel are not too expensive. The costs incurred in each marketing channel consist of transportation costs, labor costs, and packaging costs. The cheaper the costs incurred, the more efficient the marketing channel can be. In addition, the distribution of profits for each marketer is quite fair. Every profit obtained is in accordance with the marketing function being carried out.

Based on the information in Table 4, it can be concluded that the most efficient marketing channel is in Marketing Channel 2. This is because the price received by producers tends to be fixed and the price paid by consumers occupies the lowest price position compared to marketing channel 1 Marketing Channel 2 producers of processed agro-industry entrepreneurs obtain the lowest total marketing margin and the highest farmer's share.

\section{Conclusions and Suggestions}

Referring to the results and discussion and analysis of the data in this study, it can be concluded as follows where producers of processed food products in Mataram City receive the most income on average between IDR 5,000,000 to IDR 9,000,000 in a month.. Marketing channels for processed agro-industry products in the city of Mataram are carried out by several institutions, namely:. Manufacturers Collectors Retailers And Manufacturer retailer (SP1). The most efficient marketing channel is Marketing Channel 2 because it has the lowest total marketing margin (IDR 500 / egg) with the highest farmer's share, which is $88.89 \%$.

To further increase the income of processed agro-industry entrepreneurs (producers), they should deliver their products directly to the market because the price difference received by the producers of processed products to consumers is quite high. In addition to the marketing function, which is an important point in delivering processed products to consumers, marketing actors should be able to reduce costs more so that they can lighten the price burden received by consumers.

\section{References}

[1] Mataram City Manpower Office. 2013.

[2] Director General of Agricultural Product Processing and Marketing, Dep. Agriculture 2002.

[3] Arikunto, Suharsini. 2006. Research procedure. A Practical approach. PT. Creative Design. Jakarta.

[4] Aryo Demarto, et al. 2003. The informal sector is an alternative job opportunity for low-educated groups. Eleven March University Training Paper.

[5] Burn. 2013. Rice Marketing Margin Analysis in Kabila District, Bone Bolango Regency. Faculty of Agriculture, State University of Gorontalo.

[6] Downey, and Erickson 1992. Agribusiness Management (translation of Rochidayat Ganda and Alfonus Sirait); Second Edition. Erlangga, Jakarta.

[7] Kartasasmita M. 2011. Definition of Agroindustry. Blokspot.com. 2011.

[8] Khols, Richard L dan David Douney. 1972. Marketing of Agricultural Product; Macmillan Publishing Co, Inc. Neu York.

[9] Mubyarto. 1998; Small Industry Cost Concept. Gramedia Jakarta.

[10] Mar'atissholikhah, et al. (2013); Analysis of the Added Value of Tempe Chips Industry Scale Household; Journal of Agricultural Sciences Vol 9 No 2 (2013).

[11] Nasir, Mohammad; 1999. Social Research Methods. Indonesian Graha. Jakarta.

[12] Nurmedika. A. Marhauati. M. Max Nur Alam. 2013. Income and Value Analysis Add Jackfruit Chips to Tiara Home Industry in Palu City. Agrotekbis Vol. 1 No. 3. 2013.

[13] Prasetyo Eko. 2019. Analysis of the Calculation of Cost of Production and Determination of Product Selling Prices at PT. Perkebunan Nusantara IV (Persero) Tbk; Darmaangsa University Medan.

[14] Pranatagama, Muhammad Friendy. 2015. Efficiency and Business Marketing Mix Peanut Farmer in Darungan Village, Tanggul District, Jember Regency; Agribusiness study program, Faculty of Agriculture, University of Jember.

[15] Yuniati, M. 2009. Business Analysis of Eel Chips Agroindustry in Klaten Regency.; Program Agribusiness Studies, Faculty of Agriculture, Sebelas Maret University, Surakarta. 
[16] Sudiyono. 2004. Agricultural Marketing. UMM. Malang.

[17] Soekartawi. 2006. Agribusiness. Theory and Its Application; PT. Raja Grafindo Persada Jakarta.

[18] Soekartawi. 2002. Introduction to Agroindustry. Publisher PT. King Grafindo Persada.

[19] Sa'id, E. G, Syamsu, K, Heryandie dkk. Quality Improvement Study in Gambir Indonesia's Micro and Small Scale Agroindustry; Indonesian Journal of Agricultural Science, Vol. 15. N0. 2. 2020.
[20] Wiyono Tuso, Rukhavina Baksh (2015). Analysis of Income and Value Added Tofu Business in Wujianto Home Industry in Ogurandu Village; Bolundo District; Agrotekbis Vol 3. June 2015.

[21] Purnomo. Dui. 2007. Development Strategy Model of Patchouli Oil Agroindustry in Garut Regency; Published by the Faculty of Agricultural Industrial Technology, Pajajaran University, Bandung. 